THE CAMBRIDGE COMPANION TO

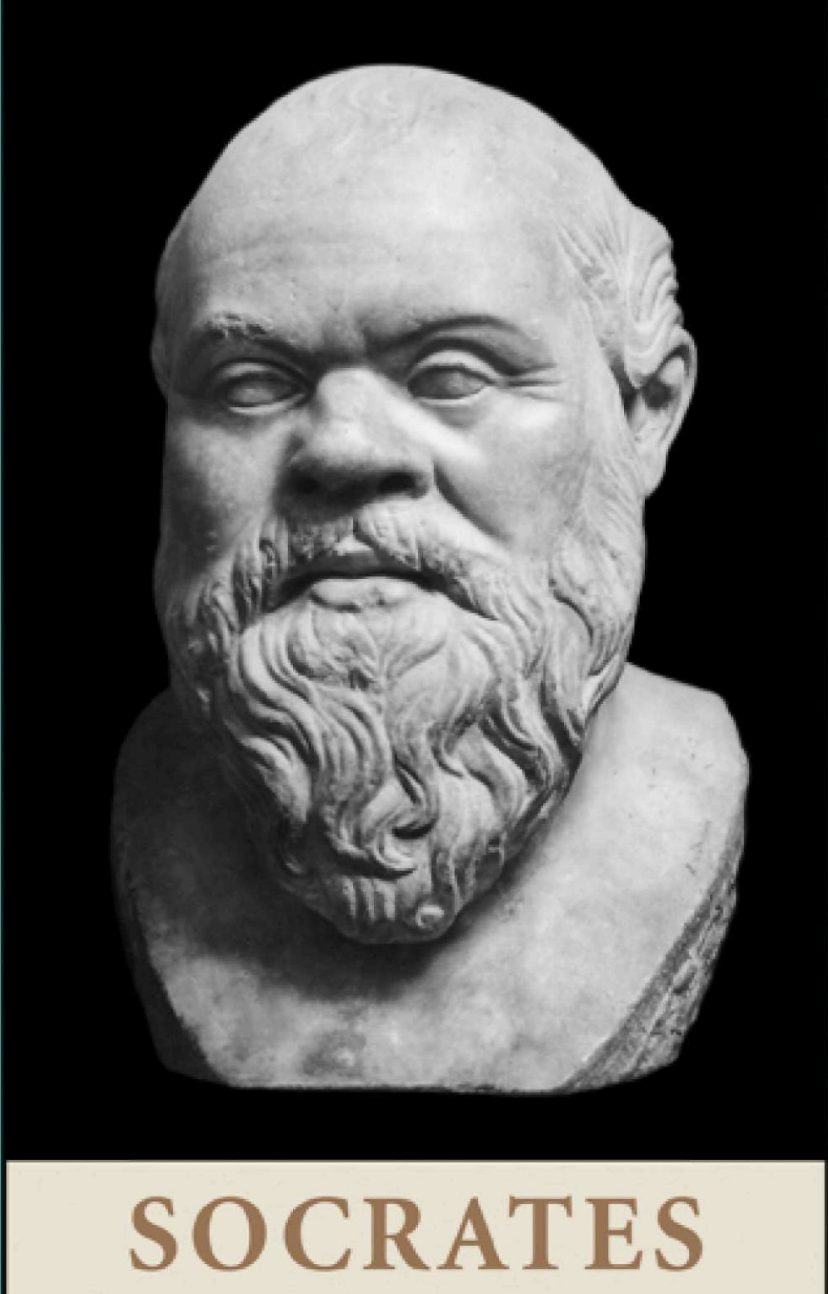

EDITED By Donald R. Morrison 


\section{The Rise and Fall of the Socratic Problem}

The Socratic problem has quite a history, and is now perhaps only a part of history, since its desperately unsolvable nature does not seem to guarantee it much of a future. It would undoubtedly be presumptuous to claim that the Socratic problem is a closed issue simply because it is not amenable to a satisfactory solution, but it is certainly useful to identify the principal obstacles and pitfalls that render the discovery of a solution improbable, or even impossible.

Socrates, as we know, wrote nothing. His life and ideas are known to us through direct accounts - writings either by contemporaries (Aristophanes) or disciples (Plato and Xenophon) - and through indirect accounts, the most important of which is the one written by Aristotle, who was born fifteen years after Socrates' death (399). Because these accounts vary greatly from one another, the question arises as to whether it is possible to reconstruct the life and - more importantly - the ideas of the historical Socrates on the basis of one, several, or all of these accounts. The "Socratic problem" refers to the historical and methodological problem that historians confront when they attempt to reconstruct the philosophical doctrines of the historical Socrates. Any future stance on the Socratic problem, if it is to be an informed and well-grounded one, presupposes a full understanding of the origins and consequences of the proposed solutions of the last two centuries. ${ }^{\mathrm{I}}$

Translated from the French by Melissa Bailar.

I Reviewing all attempts at a solution would be tedious and useless. I will limit myself to those studies I find to be the most representative or the most significant. For an excellent overview of the literature on the Socratic problem, see Patzer 1987, pp. I-40. Montuori 1992 pulled together a very useful anthology of the principal texts on the Socratic problem. 


\section{THE GENESIS: SCHLEIERMACHER AND}

THE CRITIQUE OF XENOPHON

According to the unanimous opinion of historians, ${ }^{2}$ the text that contributed the most to the development of the Socratic problem is Schleiermacher's study entitled "The Worth of Socrates as a Philosopher" (I8 I 8). ${ }^{3}$ Although certain passages from this seminal work of Socratic studies are often cited, Schleiermacher's work remains largely unappreciated. This lack of recognition is counterproductive because scholars attempting to solve the Socratic problem are often unaware that they are relying on arguments rooted in Schleiermacher that do not stand up to critical analysis. ${ }^{4}$

Schleiermacher starts from the observation that there is a contradiction between the importance of the new beginning attributed to Socrates in the history of Greek philosophy, on the one hand, and the banality of typical representations of Socrates, on the other. According to the latter, Socrates was occupied exclusively with moral questions, concerned himself above all with bettering his disciples, questioned his interlocutors on the best type of life available to mankind, and so on. If Socrates' contribution to philosophy were limited to questions of this sort, we would no longer have any reason, according to Schleiermacher, to see in him the man who was the inspiration for a sort of second birth of Greek philosophy. Schleiermacher thus rejects in their entirety the principal characteristics that constituted the traditional representation of Socrates the "philosopher" at the beginning of the nineteenth century. Because until then scholars had turned primarily to Xenophon to determine the content of the historical Socrates' ideas, ${ }^{5}$ it is hardly surprising that Schleiermacher distanced himself from Xenophon's account. In fact, he criticized the author of the Memorabilia on two points:

(a) Xenophon was not a philosopher, but rather a soldier and politician, and was thus not the most qualified witness to give a faithful account of Socrates' principal philosophical positions (I8I 8: $56=$ I879: Io). Schleiermacher's criticism presupposes that philosophy

See Magalhães-Vilhena I952, pp. I3 I, I38, I58, and I86; Montuori I98 Ia, p. 3I; I98Ib, pp. 7, 9, I I; I988, pp. 27-28; Patzer I987, pp. 9-IO.

3 For the English translation of this text, see Schleiermacher I879. See also Dorion 200I for an analysis of this text by Schleiermacher.

4 In this way, Brickhouse and Smith 2000, pp. 38, 42-43, discredit Xenophon's account by using two arguments that, although the authors seem unaware of it, could already be found in Schleiermacher.

5 For a study of the importance of Xenophon's accounts before the start of the nineteenth century, see Dorion 2000, pp. VIII-XII. 
is essentially a speculative activity. Thus, since Xenophon's Socratic writings are hardly speculative, Schleiermacher naturally concludes that Xenophon was not a philosopher and that he did not do justice to Socrates' profound philosophical positions. This is in a way an unjust attack on Xenophon, whose admitted goal, as he proclaimed at the start of the Memorabilia (I.3.I and I.4.I), was to show how and to what extent Socrates was useful to others and contributed to the bettering of his companions through both his example and his words. Are not being useful to others and bettering them worthy objectives of a philosophy understood as a way of life? In any case, this criticism received great acclaim, and commentators seeking to discredit Xenophon's account have used it ever since. ${ }^{6}$

(b) Xenophon was so zealous in defending his master against accusations regarding his subversive teachings that Socrates figures in his writings as a representative of the established order and the most traditional values. The positions that Xenophon's Socrates defends are so conservative and conventional that it is impossible to understand how such a flat and dull philosopher could attract, captivate, and maintain the interest of naturally speculative thinkers, such as Plato and Euclid, the founder of the Megarian school. In short, if Socrates had resembled the Socrates of Xenophon's writings, he would not have been surrounded by such disciples; he would instead have repelled them. ${ }^{7}$ At the start of the twentieth century, Xenophon's detractors followed Schleiermacher's lead and pushed his criticism of the apologetic nature of Xenophon's Socratic writings even further, saying, for example, that Xenophon defended Socrates so well against the accusations against him that it is difficult to understand how Socrates could possibly have been sentenced to death. (See Burnet I9I4: p. I49; Taylor 1932: p. 22.)

It is thus clear to Schleiermacher that Socrates must have been more than what Xenophon said about him, because if Socrates only amounted to his portrait in the Memorabilia, the immense philosophical influence we attribute to him would be incomprehensible: "And not only may Socrates, he must have been more, and there must have been more in the back-ground of his speeches, than Xenophon represents." (I879: I I = I 8I 8: 57) This harsh judgment is nevertheless belied by texts terms. 
and accounts that attest that the Memorabilia exerted a considerable influence on the first Stoics. ${ }^{8}$ But where does Schleiermacher intend to find this other dimension of Socrates that is presumably absent in Xenophon's text? Schleiermacher intends to find the more philosophical dimension of Socrates - "philosophical" in the modern and speculative sense of the term - in Plato, of course. But whatever is found in Plato should not contradict certain given facts in Xenophon's account that are widely recognized as reliable. Schleiermacher states in the form of a question his suggested method for reconstructing the philosophical content of the historical Socrates' thought:

The only safe method (Der einzige sichere Weg) seems to be, to inquire: what may Socrates have been, over and above what Xenophon has described, without however contradicting the strokes of character (Charakterzügen), and the practical maxims (Lebensmaximen), which Xenophon distinctly delivers as those of Socrates: and what must he have been, to give Plato a right, and an inducement, to exhibit him as he has done in his dialogues? (1879: I4 = I 8 I 8: 59)

This "method" raises more problems than it can possibly hope to resolve. As far as the "practical maxims" or the "rules of life" (Lebensmaximen) are concerned, a single example will suffice to illustrate the pitfalls obstructing the application of Schleiermacher's so-called method. Book IV, Chapter 5, of the Memorabilia is devoted to the way in which Socrates assisted his companions in regulating their behavior. In reading this chapter, it appears that self-mastery (enkrateia) is the surest foundation for behavior and action. If self-mastery is the sine qua non condition for all successful practical activity, it is hardly surprising that Xenophon affirms that enkrateia is the foundation of virtue (Memorabilia I.5.4). Must we consider, then, that the principal role attributed to enkrateia has the value of a "practical maxim"? If so, Xenophon's account would have precedence over Plato's as far as this essential aspect of Socratic ethics is concerned. In fact, since Plato's Socrates grants no theoretical importance to enkrateia - the term enkrateia is not found in Plato's first dialogues, and the idea that moderation (sôphrosunê) is in any sense reducible to enkrateia is also not found in the Charmides and because he attributes to knowledge the role that Xenophon attributes to enkrateia, his position appears irreconcilable with a practical maxim defended by Xenophon's Socrates and must, in accordance with Schleiermacher's method, be sacrificed. As can be seen, this "method" leads to results that are at times contrary to those that Schleiermacher I988, pp. I62-I63; Dorion 2000, p. 33 N. 23 I. 
had anticipated. The difficulties raised by this method notwithstanding, it did exert exceptional programmatic influence in as much as it defined the program of research followed by several generations of philosophers in their attempt to determine the philosophical content of the historical Socrates' thought. Schleiermacher's method enjoyed a considerable success, as is demonstrated by the very large number of historians who adhere to or refer to it. ${ }^{9}$

After a considerable time, Schleiermacher's essay eventually led to the full rejection of Xenophon's account. The critical movement he initiated grew over the course of the nineteenth century, and reached its height in I9I5 when Xenophon's Socratic writings had become completely discredited. To Schleiermacher's two criticisms, nineteenthand early twentieth-century historians added eight others. ${ }^{10}$ Nearly a century after Schleiermacher's seminal article and in the space of only a few years, scholars in France (Robin I9 Io); England (Taylor I9 I I; Burnet I9 I I and I 9 I4); and Germany (Maier I9I3) published in rapid succession and completely independently from one another studies that were so critical of Xenophon's Socratic writings that it was no longer clear what merit could possibly be attributed to the author of the Memorabilia.

The consensus that emerged during this period is neither accidental nor a coincidence, and in fact represents the end result of the movement launched by Schleiermacher a century earlier. From there, it was only a small step to claim that Xenophon is completely worthless to us, as Taylor and Burnet $\mathrm{did}^{\text {II }}$ and that the historical Socrates completely corresponded to Plato's Socrates. Burnet and Taylor's position thus seems to be the culmination and logical conclusion of Schleiermacher's attack on Xenophon's Socratic writings at the start of the nineteenth century. Even if it is generally agreed that Burnet and Taylor's thesis is too extreme, and that Plato's Socrates cannot be simply equated with the historical Socrates, twentieth-century scholarship has in a sense endorsed their work by ostracizing Xenophon's Socrates and by deeming Plato's Socrates the only one worthy of any interest whatsoever. ${ }^{\mathrm{I2}}$ Although the historical development of the Socratic problem has been

9 See the numerous references given by Dorion 2000, p. XIII, n. 2.

IO For a detailed presentation of these critiques, see Dorion 2000, pp. XVII-XCIX.

I I See Burnet I9I4, p. I50: “It is really impossible to preserve Xenophon's Sokrates, even if he were worth preserving."

I 2 See, among others, Vlastos I97I, p. 2: Plato's Socrates is "in fact the only Socrates worth talking about"; Santas I979, p. X: "It is only Plato's Socrates that is of major interest to the contemporary philosopher"; Kahn I98I, p. 3 I 9: "As far as we are concerned, the Socrates of the dialogues [i.e. Plato's] is the historical Socrates. He is certainly the only one who counts for the history of philosophy." 
far from linear, the overwhelming majority of the scholarly work dating from the beginnings of the Socratic problem until I9I 5 completely reversed the prevailing situation of I 8 I 5 against which Schleiermacher rebelled, to the benefit of Plato. If the disgrace that Xenophon's Socratic writings suffered were the immediate consequence of the birth and development of the Socratic problem, in contrast, the recent renewal of interest in them is largely due to the decline of this problem.

\section{THE IMPASSE AND THE FALL: THE FICTIONAL NATURE OF THE LOGOI SOKRATIKOI}

The nearly unanimous discredit that befell Xenophon's Socratic writings nonetheless did not bring about a solution to the Socratic problem. Historians continued to debate the value of the three other sources, with the majority of them giving priority to Plato, others to Aristotle, ${ }^{13}$ and a final few to Aristophanes. ${ }^{14}$ In short, if everyone, or nearly everyone, agreed to reject Xenophon's accounts, no one was in agreement over the respective reliability of the three other sources. It is probably impossible to reconstruct the ideas of the historical Socrates from Aristophanes' The Clouds, not only because the very genre of comedy lends itself to exaggeration and even excess, but also because there is good reason to believe that Socrates' character in The Clouds is really a composite figure whose traits were gathered not only from Socrates himself but also from the physiologoi and the sophists. ${ }^{15}$ The case of Plato's account especially highlights the absence of consensus; if we consider only those commentators who are inclined to grant priority to Plato's dialogues, we notice that they do not turn to the same dialogues to reconstruct the historical Socrates' theories. Some rely mostly on the Apology, ${ }^{16}$ many base their work on the entirety of the early dialogues, ${ }^{17}$ or on just a few of them, others still call on the apocryphal dialogues, ${ }^{18}$ and finally some consider that every word that Plato put in Socrates' mouth, whether in an early, middle, or late dialogue, has a place in the record of the historical Socrates. ${ }^{\text {I9 }}$ It is quite surprising that there is

I 3 Joël I 893, I, p. 203.

I4 See the numerous references indicated by Montuori I988, p. 42, n. 36. H. Gomperz I924 went so far as to claim that the historical Socrates was found not in The Clouds but in fragments of other comedies!

I 5 See Ross I933, p. Io; Dover I968, pp. XXXVI, XL; Guthrie I97 I, p. 52; Vlastos I97 I, p. I, n.I and the many authors mentioned by Montuori I988, p. 4I, n.35.

I6 See infra pp.I7-I8.

I7 See Maier I913; Guthrie I975, p. 67; Vlastos I991, pp. 45-50; Graham I992; Brickhouse and Smith 2000, pp. 44-49; 2003, pp. I I 2-I I 3.

I8 See Tarrant I938.

I9 This is the position defended by Taylor I9I I, p. IX, and Burnet I9I I; I9I4. 
no consensus regarding the number and identity of Plato's dialogues that would allow for the reconstruction of the historical Socrates' ideas, but, in another way, this disagreement among interpreters is inevitable because of the doctrinal heterogeneity of Socrates' character in the corpus platonicum. ${ }^{\circ}$

The lack of consensus and the proliferation of attempted solutions undoubtedly led to the scholarly works running out of steam, but this did not necessarily mean that the Socratic problem was a false problem to which a solution could never be found. The position that would finally evoke a lasting skepticism surrounding the Socratic problem was initiated in Germany in the last quarter of the nineteenth century. This major discovery, credited primarily to K. Joël (I895-I896), is that of the fictional nature of the logoi sokratikoi.

The Socratic problem has all the makings of a false problem because it rests on a misunderstanding. This in turn entails an inevitable misinterpretation of the exact nature of the preserved "testimony" about Socrates. For the Socratic problem as it had been debated since the start of the nineteenth century to have meaning, the principal direct witnesses (Xenophon and Plato) must have intended to faithfully reconstruct Socrates' ideas through writings that aimed to transmit at least the spirit and content, if not the exact words, of Socrates' dialogues. If this had been their intention, we would be justified in asking which account best corresponds to the thought of the historical Socrates. Yet everything seems to indicate that neither Xenophon nor Plato set out with the intention of faithfully reporting Socrates' ideas. Xenophon's and Plato's Socratic writings belong to a literary genre-that of the logos sokratikos, which Aristotle ${ }^{21}$ explicitly recognized and which authorizes by its very nature a certain degree of fiction and a great freedom of invention as far as the setting and content are concerned, most notably with the ideas expressed by the different characters. Yet, since Aristotle sees in the logoi sokratikoi a form of mimêsis (imitation), would we not be well justified in considering them faithful documents that aim to accurately reproduce the life and thought of Socrates? This is precisely how Taylor interpreted Aristotle's account of the logoi sokratikoi: "Aristotle [...] regards the 'Socratic discourse' as a highly realistic kind of composition. You cannot, of course, infer that he holds that the actual Socrates must have really made every remark ascribed to him in such a discourse, but

20 Montuori I98Ia, p. 225: "It is important to underline that Plato does not give us a single image of Socrates, coherent and complete, but a disconcerting plurality of images, all of which have been noted by the critics, who in turn have taken one or the other as the most faithful description of the historical person of Sophroniscus's son." See also p. 226.

2 I SeePoetics I. I447a28-bi3; Rhetoric 3.I6.I4I7aI 8-2 I;fr.72Rose(=Athenaeus I5.505 C). 
it would not be a proper 'imitation' of Socrates unless it were in all its main points a faithful presentation." (I9II, p. 55) A lot is at stake in the interpretation of Aristotle's testimony, because if the mimêsis is understood as a faithful imitation of reality, in principle nothing keeps us from considering the logoi sokratikoi to be a reliable and privileged material aiming to reconstruct the life and thought of Socrates; on the other hand, if the mimêsis, as Aristotle understands it, is a creation that authorizes a degree of fiction and invention, the task of reconstructing the thought of Socrates based on the logoi sokratikoi seems doomed to fail. According to Joël, then, Aristotle's account establishes that the logos sokratikos, classified as a form of mimêsis, allows for a substantial amount of fiction and invention, as far as both the setting and the ideas expressed by the characters are concerned. The recognition of the fictional character of logoi sokratikoi did not immediately gain acceptance without debate or controversy. ${ }^{22}$ It is to Joël's immense credit that he brought this essential dimension of logoi sokratikoi to light; it is likewise unfortunate that this important discovery is not always credited to him. ${ }^{23}$

Since logoi sokratikoi are literary works in which the author can give his imagination free reign, while remaining within the plausible bounds of a credible representation of Socrates' êthos, the degree of fiction and invention inherent in logoi sokratikoi means they cannot be considered as accounts written for their historical accuracy. This does not mean, of course, that the logoi sokratikoi contain no single authentic trait or accurate detail; but as the historical concern of logoi sokratikoi is only incidental, and since we do not have at our disposal the criteria that would allow us to separate invention from authenticity, it would certainly be more prudent to renounce any hope of finding the "true"

22 On the debate surrounding the nature and status of the logoi sokratikoi, see Deman I 942, pp. 25-33. In the years following the publication of Joël's study, numerous commentators agreed with him and recognized the fictional nature of the logoi sokratikoi (see Robin I9Io, p. 26; Maier I9I3, p. 27, n. I; Dupréel I922, pp. 457-460; Magalhães-Vilhena I952, pp. 225, 326, 345,35 I, 370, etc.).

23 Momigliano's works I97 I, pp. 46-57, are often cited to justify affirming the logoi sokratikoi's fictional nature (see Vlastos I99I, pp. 49, n. I4, 99 n.72; Kahn I992, pp. 237-238; I996, pp. 33-34; Beversluis I993, p. 300, n. I4; Vander Waerdt I993, p. 7; 1994, p. 2, n. 6). In fact, searching Momigliano's work for a precise argument that attempts to demonstrate the fictional character of the logoi sokratikoi is fruitless (see Dorion 2000, pp. CVIIICXI). Furthermore, Momigliano never refers to Aristotle's account of the logoi sokratikoi, even though it is precisely this account that authorizes evaluating the logoi sokratikoi as literary creations. 
Socrates in these writings. Furthermore, if we consider the fact that many of Socrates' disciples wrote logoi sokratikoi, ${ }^{24}$ and that there is good reason to believe that the portraits of Socrates differed greatly from one author to the next, and sometimes even within the same author's writing, ${ }^{25}$ it is likely that Socrates rapidly became a sort of literary character (dramatis persona) endowed with his own existence and placed at the center of the polemics and rivalries that pitted one Socratic against another. ${ }^{26}$ Each author of logoi sokratikoi in this way created "his own" Socrates, whom he contrasted with the competing Socrates' outlined by the other Socratics. Each laid claim to, and quarreled over, the heritage of their bygone master, as well as faithfulness to his memory and his teachings.

If the logoi sokratikoi cannot be read or interpreted as historical documents in the strictest sense, but rather as literary and philosophical works that include a substantial degree of invention, even concerning the ideas expressed, then the Socratic problem seems hopelessly deprived of the "documents" from which the elements of a solution could be unearthed and the key to the enigma found. If our principal sources are already interpretations, we must recognize all that this entails: first, we cannot favor one interpretation over another, since nothing justifies such a bias on the historical level, and second, attempting to reconcile them all would be in vain, because such agreement would be either impossible or superficial. It is often impossible because of the many insurmountable contradictions in Plato's and Xenophon's accounts. ${ }^{27}$ It is not the case that

the Socrates of Plato's early dialogues agrees with the versions of Socrates in Xenophon, Antisthenes, Aeschines, and also the spurious Platonic dialogues (see D. Tarrant 1938), e.g. in practicing the style of refutation known as the

24 According to Diogenes Laertius, Antisthenes (6.I 5-I 8), Aeschines (2.60-63), Phaedo (2.105), and Euclid (2.108) composed Socratic dialogues. Diogenes Laertius (2.I2I-I25) attributes logoi sokratikoi to several other Socratics as well (Crito, Simon, Glaucon, Simmias, Cebes), but this evidence should be treated with caution. It is generally accepted that Aristippus did not compose Socratic dialogues.

25 I am thinking primarily of Plato, whose representation of Socrates evolved so considerably from the early to the middle dialogues that we are really dealing with two Socrateses, irreducible and opposed to one another, as Vlastos clearly demonstrated (I99I, pp. 45-80).

26 See Gigon I 947, p. 3 I 4: "The Socratic literature is primarily self-presentation of the Socratics, of their own philosophical thought and their literary (dichterisches) abilities."

27 See the list of the seventeen major contradictions on the philosophical level (Dorion 2006, pp. 95-96). This list is not exhaustive. 
elenchus, professing ignorance of major questions, and having a philosophical mission. (Graham I992, p. I43 n.9)

This claim reveals a significant misunderstanding of Xenophon's Socratic texts, for Xenophon's Socrates hardly ever practices the elenchus, never acknowledges his ignorance regarding the most important questions, and in contrast to Plato's Socrates, never identifies a philosophical mission. And when agreement is possible between Plato and Xenophon, it is more often than not superficial. Not only does such agreement not necessarily guarantee an objective fact; it is usually nothing but a superficial concordance that might mask more fundamental discrepancies. There are, of course, many Socratic themes common to Xenophon and Plato, but such overlapping does not indicate a common theory that could be attributed to the historical Socrates. To "demonstrate" a fundamental agreement between Plato and Xenophon, Luccioni (I953, pp. 48-56) was naïve enough to believe that drawing up a list of several dozen common themes (the divine sign, virtue as science, piety, self-knowledge, the dialectic, his rejection of the study of nature, etc.) would suffice. In fact, it is easy to demonstrate that Xenophon's treatment of any one of these themes cannot be assimilated with Plato's treatment of it. The differences in the treatment of these common themes are so important that the least common denominator amounts to very little in most cases. For example, self-knowledge is a privileged theme in the reflections of both Plato's and Xenophon's Socrates, but their respective conceptions of self-knowledge are so different from one another that it is impossible to tease out any features of a common theory. Furthermore, the sporadic agreements between Plato and Xenophon are not as significant as some might suggest. Take the case of the Delphic oracle: both Plato (Apology 20e-23b) and Xenophon (Apology I4-I6) certainly attest to it, but this nevertheless does not mean that it constituted an actual episode in Socrates' life. In fact, there is nothing to say that it is not a myth first invented by Plato and later taken up and reinterpreted by Xenophon. It would be a mistake to believe that an agreement between two texts allowing the use of fiction is indicative of an objective fact (see Joël I 895: 478). Moreover, the existence and significance of the many differences between these two versions are not really apparent without an exegetic study that would seek to understand them in light of the respective and consistent representations that Plato and Xenophon created of Socrates and the fundamentals of his ethics. The oracle's response in Xenophon's Memorabilia appears as a sort of condensed or concentrated version of the ethics defended by Socrates, which justifies the claim that, "Xenophon has reformulated Plato's account of the oracle's response in the service of his own understanding of Socratic ethics." (Vander Waerdt I994, p. 39) 
Rather curiously, K. Joël did not explore all of the consequences of his valuable discovery. If it is futile to attempt to resolve the Socratic problem on the basis of texts that do not aim to faithfully reproduce the historical Socrates' teachings, how is it that Joël himself did not give up the hope of finding a solution to this problem? This apparent paradox is explained by the fact that Joël believed he was in a position to resolve the Socratic problem by turning to an account that is not itself a logos sokratikos, in this case that of Aristotle (see I893, I, p. 203). Yet if Aristotle's account is not an independent and objective source, as it is essentially dependent on Plato's Socratic writings, as Taylor would later demonstrate, ${ }^{28}$ then the Stagirite's account of Socrates cannot provide the solution to the Socratic problem. Furthermore, even if Aristotle's account at times appears independent of Plato's Socratic writings ${ }^{29}$ and of other logoi sokratikoi, its extremely narrow scope would not allow us to progress far at all. What Aristotle has to say about Socrates is extremely limited, and in fact his silence on a host of subjects means that his account cannot provide the infallible arbitration that Joël had hoped for. For example, in regards to Socrates' daimonion, the importance of enkrateia, his understanding of piety, his conception of the elenchus, the nature of his political engagement, his interpretation of the statement "know thyself," and his attitude toward the lex talionis, all of which are subjects that are irreconcilable in Xenophon's and Plato's accounts, Aristotle is of no help because he provides no pertinent information. Furthermore, we cannot rule out the possibility that Aristotle's account of Socrates more often than not has an "ulterior motive," in the sense that the Stagirite interpreted Socrates to fit with his own priorities, so that it would be erroneous to consider it an objective and impartial account. ${ }^{30}$

Let us put all of this in perspective. If we have strong reasons to be skeptical of the possibility of resolving the Socratic problem - that is, of reconstructing the philosophy of the historical Socrates, just as he explained and defended it in front of different audiences in Athens during the second half of the fifth century вСЕ - there are certain facts about Socrates of which we have no good reason to be suspicious. First, there is information concerning Socrates' biography and appearance.

28 See Taylor I9I I, pp. X, 40-90; I932, p. I7, n. I; Burnet I9I I, pp. XXIII-XXV.

29 The source of the passages in the Metaphysics (A 6.987bI-6; M 4.I078b 7 -32; M 9.1086a37-b5) that attribute the paternity of the theory of intelligible forms to Plato and not to Socrates could not possibly be Plato's dialogues. This is an important but purely negative piece of information: Socrates did not develop the theory of intelligible and separate forms.

30 This is a common criticism of Aristotle, most notably in Kahn 1992, pp. 235-239; I996, pp. 79-87. 
We know, for example, that Socrates was born in Athens in 470, that he came from the deme of Alôpekê, and that he was sentenced to drink hemlock after he was judged guilty in 399 of each of the three charges that Meletus, Anytus, and Lycon accused him of: corrupting youth, introducing new divinities, and not believing in the state gods. On the other hand, scholars still debate over the exact reasons underlying and motivating the three charges. As far as Socrates' appearance is concerned, Plato (Theaetetus I43e) and Xenophon (Symposium 2.I9, 5.5-7) do not paint a flattering picture: Socrates has a broad nose, bulging eyes, thick lips, and a large belly - in short, his physique seems so unappealing that his two disciples do not hesitate to compare him to a Silenus. ${ }^{3 \text { S Second, }}$ the textual evidence provides some insight into Socrates' philosophical interests. Because Xenophon's and Plato's accounts of Socrates share many common themes, it is almost certain that they are Socratic themes - that is, philosophical positions that the historical Socrates explained and defended. But it is important to remember that we are often forced to affirm that Socrates supported one position or another without being able to reconstruct with any certainty the full details of these positions, because the reasons and arguments that underlie them are often quite different if we turn to Plato or to Xenophon.

Just as several decades passed before the critical movement initiated by Schleiermacher's article was carried through to its conclusion, the ultimate consequences of Joël's discovery were not reached until the first half of the twentieth century. It was a Belgian scholar, E. Dupréel, who was the first to adopt a resolutely skeptical position concerning the Socratic problem (I922, pp. 398, 4I2-4I3, 426). But it was undeniably O. Gigon who contributed the most to establish the fact that because the Socratic problem was predicated on erroneous assumptions, it was a false problem whose solution could not be found. His book on Socrates (I947) is a vibrant manifesto in favor of abandoning the Socratic problem and a stimulating illustration of another type of research into Socrates and the Socratic tradition. If, because of the conventions of the genre, Socratic literature always involves an irreducible element of fiction, invention, and creativity (Dichtung), then it must be studied in and of itself as such. In other words, we should be attentive to the variations that we can find among the different versions of a single Socratic theme in order to throw light on the significance and the scope of the variations on the philosophy and the representation of Socrates. ${ }^{32}$ This is a rich field of research that has still not yielded all that it promises. ${ }^{33}$

32 See I947, pp. 34, 68, and the chapter titled "Die Sokratesdichtung" (pp. 69-I78).

33 If the work of Joël, Dupréel, and Gigon has, in certain respects, become dated, it is above all due to the gratuitous hypotheses they constructed in 
Joël's works allowed us to rediscover in the logoi sokratikoi a truth that had already been well known to the Ancients themselves. One of the reasons the Ancients never debated the Socratic problem is because they fully recognized the fictional nature of the logoi sokratikoi. This is demonstrated by the aforementioned passages from Aristotle as well as by several anecdotes and accounts expressing a profound skepticism regarding the historicity of the subjects and theories that Socrates expresses in the dialogues in which he figures as the protagonist. The following anecdote related by Diogenes Laertius is quite instructive: "They say that, on hearing Plato read the Lysis, Socrates exclaimed, 'By Heracles, what a number of lies this young man is telling about me!' For he has included in the dialogue much that Socrates never said." (3.35; trans. Hicks) This anecdote is misleading insofar as the composition of the Lysis likely occurred after Socrates' death, but, on the other hand, it also contains an element of truth in that it fully acknowledges the fictional nature of logoi sokratikoi. Athenaeus (I I.507c-d) also recounts an amusing anecdote with an analogous meaning. Socrates relates one of his dreams: Plato, transformed into a crow, was perched atop his bald head, where he hopped about while looking around. To Socrates, this dream meant that Plato would tell many lies about him. ${ }^{34}$ Likewise, Cicero (Republic I.Io, I5-I6) did not allow himself to be deceived by the setting and characters of Plato's dialogues: he was convinced that Plato attributed to Socrates theories that were actually of Pythagorean origin. ${ }^{35}$ In addition, the presence of many anachronisms in the logoi sokratikoi of Plato, Xenophon, and also Aeschines ${ }^{36}$ likewise serves to demonstrate that the authors of Socratic dialogues treated historical truth lightly and that their poetic license was probably recognized because of the conventions of the genre. Finally, it would be a mistake to think that the fictional nature of the literary Socrates was a phenomenon posterior to the first dialogues written out by Socrates' disciples, because the existence of at least two portraits of Socrates within Plato's

the framework of "source research" (Quellenforschung). However, a legitimate criticism of the Quellenforschung's excess does not necessarily lead to a complete rejection of Joël's accurate and profound intuition that a logos sokratikos must be interpreted as a philosophical work in which the character named Socrates is often the spokesman of the author's theses and arguments, which are themselves in opposition to other theses and arguments that a character named Socrates formulated in other logoi sokratikoi. The thesis of fictionality does not necessarily lead to the extreme positions of the Quellenforschung.

34 See also Ir.505d-e.

35 See also D.L. 2.45; Proclus in Alcibiades I8.I5-I9.I2 Creuzer.

36 On the many instances of historical implausibility in the settings and characters of Aeschines' dialogues, see Kahn I996, pp. 27-28. 
works confirms that the fictional dimension of Socratic literature dates back to its very origins.

The position of those who recognize the fictional nature of the logoi sokratikoi but who nonetheless hope to resolve the Socratic problem is methodologically untenable, and raises more problems than it can possibly solve. Two recent and quite different examples serve as proof that we have reached an impasse with the Socratic problem. My first example comes from G. Vlastos. Although he recognizes the fictional and creative nature of the logoi sokratikoi (I99 I, pp. 49-50), he believes nonetheless in the historicity of the Socrates depicted in Plato's early dialogues (I 99 I, pp. I n. 2, 53, 8I, 90-9 I, etc.). This position seems at first to be belied by another thesis that Vlastos develops in his work-namely, the presence of two Socrateses - the Socrates of the early dialogues (Socrates ${ }^{\mathrm{E}}$ ) and the Socrates of the middle dialogues (Socrates ${ }^{\mathrm{M}}$ ) - who uphold diametrically opposed positions on ten specific subjects. In fact, if Plato, as Vlastos admits, believed that he was authorized to have Socrates ${ }^{\mathrm{M}}$ be the spokesman of theses that were actually Platonic, is this not proof that the fictional nature of the logoi sokratikoi extends to the content of the theories attributed to Socrates? And if Vlastos readily recognizes that the ten theses that Socrates ${ }^{\mathrm{M}}$ developed are not Socratic, how can he be sure that the positions Socrates ${ }^{\mathrm{E}}$ expresses belonged to the historical Socrates and are not positions Plato felt authorized to attribute to his character of Socrates by virtue of the poetic license allowed by the conventions of the literary genre of the logos sokratikos? Vlastos himself raises this possibility, ${ }^{37}$ and his argument against it consists of affirming that on several important points, the portrait of Socrates ${ }^{\mathrm{E}}$ is confirmed and corroborated by Aristotle's and Xenophon's accounts.

The way in which Vlastos treats Xenophon is rather singular: when his account agrees with Plato's, Vlastos is quick to mention it and to view it as a guarantee of the truthfulness of the Platonic account (I99I, pp. 99-I06), but when it is irreconcilable with Plato's account, Vlastos strives to discredit it by using arguments that are in fact nothing more than old biases pulled from the arsenal of objections that Schleiermacher and the nineteenth- and early-twentieth-century critics of Xenophon had already formulated..$^{38}$ To cast doubt on the strictly philosophical

37 See I99I, p. 8I: "For there is no intrinsic reason why both of these philosophies, despite their polar differences, could not have been Plato's own original creations at different periods of his life." See also Graham I992, p. I44.

38 Of the ten criticisms regularly directed toward Xenophon, Vlastos draws on four - namely, Xenophon was not an actual disciple of Socrates (see I99I, p. I03); he was not an eyewitness of the conversations he reports (see I99I, pp. 49, n. I 4, 99 n.72); he is excessively zealous in his apologetics (see I988, p. 92); he did not have the necessary philosophical aptitude to faithfully 
value of Xenophon's account, Vlastos strives to highlight supposed contradictions whose very presence in the text of the Memorabilia would, he claims, justify a wary attitude toward Xenophon. To choose one example, Vlastos suggests this would be the case with the account of the impossibility of the weakness of will, or akrasia (I99 I, pp. 99-IOI); yet it is possible to demonstrate that Xenophon's account is in fact perfectly coherent and that its supposed contradictions can actually be attributed to errors in Vlastos' interpretation (see Dorion 2003).

All evidence suggests that Vlastos grossly overestimated the agreement between Xenophon and Plato. Keep in mind that the positions that Vlastos examines are the following: (I) The philosophy of Socrates ${ }^{\mathrm{E}}$ is exclusively a moral philosophy. (2) Socrates ${ }^{\mathrm{E}}$ did not develop a metaphysical theory of intelligible and separate forms. (3) Socrates ${ }^{\mathrm{E}}$ searches for knowledge through refutation, and professes over and over that he has no knowledge. (4) Socrates ${ }^{\mathrm{E}}$ did not develop a tripartite conception of the soul, which would have undermined his theory concerning the impossibility of akrasia. According to Vlastos (I99I, pp. 99-I06), Xenophon's account would confirm positions $(\mathrm{I}),(2)$, and (3), while its confirmation of (4) would be only partial in light of the (supposedly) contradictory nature of his account. The agreement between Xenophon and Plato on all of these points would thus guarantee the historicity of the positions supported by Socrates ${ }^{\mathrm{E}}$. Yet, contrary to what Vlastos claims, Xenophon only confirms positions (2) and (4). In fact, although Xenophon's Socrates (see Memorabilia I.I.I6) is primarily concerned with questions relating to ethics (= I), he is also interested in religion (see Memorabilia I.4, 4.3, 4.6.2-4); education (see Memorabilia 4.I-3, 5-7; Apology 20); and art (see Memorabilia 3.Io), which are, as Vlastos himself admits (I99 I, p. 48), three of Socrates ${ }^{\mathrm{M}}$ 's favorite subjects. As far as $(3)$ is concerned, Vlastos goes beyond the evidence when he claims (see I99I, p. I05), on the basis of Memorabilia 4.4.9, that Xenophon's Socrates recognizes his ignorance and seeks knowledge through the elenchus, a claim that is unfounded. Xenophon's Socrates never acknowledges his own ignorance on the moral level, ${ }^{39}$ and the elenchus, which he uses in only one dialogue,$^{40}$ offers no assistance in the quest for knowledge but only in

report Socrates' ideas (see I99I, p. 99). I showed elsewhere that most of these objections do not stand up to a careful examination (see Dorion 2000, pp. XXII-XXX, XXXIX-LII, LXV-LXX, XC-XCIX, respectively).

39 Socrates acknowledges his ignorance as far as economics and agriculture are concerned (see Oeconomicus 2.I I-I3), and in those fields where he acknowledges his ignorance, he encourages his interlocutors to seek instruction from a competent master (see Memorabilia I.6.I4; 4.7.I). But Socrates certainly never views himself as ignorant when it comes to questions pertaining to ethics.

See Memorabilia 4.2 and Dorion 2000, pp. CLXIX-CLXXXII. 
the revelation of his interlocutor's ignorance. The agreement between Xenophon and Plato in the end concerns only points (2) and (4), which are purely negative positions: they boil down to stating that Socrates did not develop the metaphysical theory of separate forms, nor did he set up a tripartite conception of the soul. In brief, this agreement gives us absolutely no insight into the content of the historical Socrates' ideas. Furthermore, as I stressed earlier, such points of agreement often conceal doctrinal divergences; for example, Xenophon's Socrates and Plato's Socrates affirm the impossibility of the weakness of will ${ }^{4}$ for different reasons, and although neither develops a tripartite conception of the soul, Socrates ${ }^{\mathrm{E}}$ and Xenophon's Socrates do not ascribe the same importance to the soul at all, since the former equates it to the "self" or to the essence of what man is, whereas the latter never suggests such an equality and insists just as much on caring for the body as on caring for the soul.

Regarding Aristotle, the vast majority of positions that he attributes to Socrates can be traced to Plato's dialogues, so it is difficult to concede that Aristotle's account of Socrates constitutes an independent source. In suggesting that Aristotle's account is a guarantee of historical accuracy because it confirms Plato's account, Vlastos falls prey to a circular argument. ${ }^{42}$ If in fact Aristotle's account has no independent value, and Xenophon's does not provide the desired confirmation, Vlastos is deprived of the one and only argument that would have allowed him to escape from the hypothesis that he himself mentioned - that Socrates ${ }^{\mathrm{E}}$ is just as much the fruit of Plato's philosophical imagination as is Socrates $^{\mathrm{M}}$.

My second example is taken from C. Kahn. Since he fully recognizes the fictional nature of Socratic literature as far as the setting, characters, and content are concerned, ${ }^{43}$ it is hardly surprising that he adopts a resolutely skeptical position:

\section{I See Dorion 2003, pp. 662-664.}

42 According to Vlastos I99I, p. 97, n. 69, more than a third of the forty-two accounts Deman 1942 selects from Aristotle do not stem from Plato's dialogues. Yet the only example Vlastos provides - that Aristotle could not have learned that Plato had been Cratylus's student from the dialogues - is not very conclusive because it has nothing to do with Socrates. The way in which Vlastos uses Aristotle's account was severely criticized by those who, following Taylor's lead (I9I I, pp. 40-90), regard the Stagirite as entirely dependent on Plato and thus not an independent source (see Kahn I992, pp. 235-240; I996, pp. 79-87; Beversluis I993, pp. 298-30I; Vander Waerdt I994, p. 3, n. 7).

43 See, among others, I996, p. 88: "Plato has deliberately given himself almost total freedom to imagine both the form and the content of his Socratic conversations." 
Our evidence is such that [...] the philosophy of Socrates himself, as distinct from his impact on his followers, does not fall within the reach of historical scholarship. In this sense the problem of Socrates must remain without a solution. (I992, p. 240)

$[\mathrm{I}] \mathrm{t}$ is a fundamental misunderstanding of the nature of Socratic writings to see them as aiming at a faithful portrayal of the historical Socrates. [...] the Socratic literature, including the dialogues of Plato, represents a genre of imaginative fiction, so that $[\ldots]$ these writings cannot be safely used as historical documents. (I996, pp. 74-75)

One would thus think that the issue was settled and done with: the Socratic problem is by definition unsolvable. Yet Kahn almost immediately backs away from this conclusion and asserts that the Platonic Apology is a separate case since it is the text that has the best chance of corresponding to a "quasi-historical document" (I996, p. 88) and a "historical account" (I992, p. 257; see also 240 n. 9) of Socrates' philosophy. This position is not unique to Kahn; numerous commentators ${ }^{44}$ do not in fact consider the Apology to be a logos sokratikos because in it, Plato reports a speech that has the status of a historical event witnessed by several hundred people. This would have prevented Plato from straying too far from historical accuracy and would have forced him to recount - if not the exact words - at least the spirit of Socrates' defense before the court. If in fact the Apology were not a work of fiction like Plato's logoi sokratikoi, it would be possible, at least in theory, to reconstruct Socrates' philosophy based on the Apology. 45 However, such a position is subject to the following objections:

(I) We have no reason to exempt the Apology from the status of a logos sokratikos ${ }^{46}$ and to believe that it does not contain a degree, and perhaps a considerable degree, of fiction. ${ }^{47}$ The existence of

44 See Taylor I932, p. 28; Ross I933, pp. I 5, 22-23; Guthrie I971, p. I 58, n.I; and the references Montuori indicates in I98 Ia, pp. 42-43.

45 On the basis of the Apology, which he presents as "our measure for the historical Socrates" (I996, p. 95), Kahn (pp. 88-95) proposes a "minimal view" of the historical Socrates. For more recent attempts at reconstructing the historical Socrates' ideas on the basis of the Apology, see Döring 1987, I992, pp. 2-4.

46 See Joël I 895, p. 480, and Morrison 200ob, p. 239, whose work is a methodical refutation of those - notably Kahn and Döring (see n.45) - who regard the Platonic Apology as a viable "document" for reconstructing the historical Socrates' philosophy.

47 Thus it cannot be ruled out that the Delphic Oracle story, which plays a fundamental role in the Apology, was invented by Plato to serve as the founding myth of Socrates' philosophical mission (see Montuori r98 Ia, pp. 57, n. 6 and 8 , I40-I43; I988, p. 52 n. 8 I). 
several Apologies by different authors further confirms that the theme of Socrates' trial and defense was no less a subject of rivalry among the Socratics than other themes that they debated among themselves through the medium of the dialogues (Dorion 2005). If the Platonic Apology were a faithful report of Socrates' trial, it would then be necessary to deem other rival versions on Socrates' trial, including Xenophon's Apology, unfaithful, which brings us back to the argument from the heyday of the Socratic problem that Plato's account is superior to Xenophon's. Could we in all seriousness affirm that the Platonic Apology is a faithful report and that the other Apologies are fiction?

(2) Plato's Apology is a report not only of Socrates' trial, but also of the very fundamentals of his philosophy; this implies that the supposed faithfulness of the account must cover everything from the theories Socrates developed to the actual progression of the trial. But because the philosophical positions developed in the Apology are also present in other dialogues, it follows that we must also consider the philosophical theses of the other dialogues that conform to those of the Apology to be historically accurate. Yet we have already established that it is impossible to reconstruct the thinking of the historical Socrates on the basis of the logoi sokratikoi, since the very nature of their genre authorizes a considerable freedom of invention. If we follow this line of thinking through, Kahn's position thus leads to the acceptance of the possibility of what it denies at the start. And it follows that since Socrates' philosophy, to the extent that we can reconstruct it on the basis of the Apology and the early dialogues, differs on several points from the philosophy established in Xenophon's Socratic writings, Plato's logoi sokratikoi should thus take precedence over those of Xenophon, without any possibility of justifying such a preference..$^{8}$ And thus we are yet again mired in the quicksand of the Socratic problem.

\section{THE FUTURE OF SOCRATIC STUDIES}

Recognizing the unsolvable nature of the Socratic problem represents neither a loss for interpretive studies nor an impoverishment of exegesis; on the contrary, it is an opportunity, an exceptional occasion for

48 Kahn disqualifies Xenophon's account on the pretext that it relies on Plato's dialogues (see I996, pp. 75-79). However, Kahn greatly exaggerates Xenophon's dependence on Plato (see Morrison 200ob, p. 262 n. 42; Dorion 2000, p. LVIII, n. 2). 
enriching our understanding of Socratism. In truth, it is the Socratic problem that caused an impoverishment of exegesis because a direct consequence of limiting the scope of Socratic studies to only the Socratic problem was the exclusion of entire sections of accounts relating to Socrates - in particular Xenophon's Socratic works - under the pretext that they did not conform to what were believed to be the historical Socrates' ideas. ${ }^{49}$ Let us take the recent example of the Delphic oracle. The exegetic choices are the following: either we prefer Plato's version to Xenophon's for reasons that have more to do with bias than the possibility of ruling in favor of one over the other (Vlastos I99I, pp. 288-289); or, rather than keeping one and disqualifying the other, we conserve both versions and strive to note their differences and most importantly interpret them in the framework of the philosophical convictions specific to each of the authors (Vander Waerdt I 993). It seems quite likely that this type of comparative exegesis, because it revives the pertinence of positions hitherto discarded by the Socratic problem, will considerably enrich our understanding not only of the reception of Socratism but also of the authors who express themselves through the intermediary of Socrates.

If we must abandon the project of faithfully reconstructing the historical Socrates' ideas, so desperately out of reach, interpreters of Socrates and Socratism will certainly have their work cut out, ${ }^{\circ}{ }^{\circ}$ since a triple task awaits them:

(I) Analyze each extant logos sokratikos independently in order to reconstruct those of Socrates' doctrines that can be teased out of its narrative. As far as Plato's Socratic writings are concerned, this research, which underwent considerable invigoration following the work of Vlastos, is already quite far along. On the other hand, Xenophon's Socratic writings and fragments from other Socratics are virtually untouched territory.

49 See Vander Waerdt 1994, p. 4: "An impoverishing, if unsurprising effect of the recent scholarly preoccupation with the Platonic Socrates has been the exclusion of rival portraits of Socrates from serious study."

50 In a recent article that attempts to defend "Socratic studies," Brickhouse and Smith 2003 understand this expression in such a way that it designates only those works that endeavor to reconstruct the historical Socrates' ideas on the basis of Plato's early dialogues. If this is the only object of Socratic studies, it is hardly surprising that Brickhouse and Smith take to task those who challenge the notion that the historical Socrates' ideas can be reconstructed because it would deprive Socratic studies, as they understand the term, of its sole object and raison d'être. As the reader will shortly see, I understand by Socratic studies a far broader and diversified program of study. 
(2) Pursue comparative studies of the different portraits of Socrates left to us by his principal direct and indirect witnesses. In comparing and contrasting these different portraits, we will be better able to grasp how, and eventually why, a single theme spawned multiple interpretations more or less compatible with each other. Without going to the extremes of the Quellenforschung, we should push the analysis of the common themes in the logoi sokratikoi as far as our sources will allow, because it is precisely this intertextuality that allows us to grasp an echo of the debates that caused such a frenzy in Socratic circles. This exegetic program has been very eloquently defended by commentators who share our skepticism concerning the possibility of resolving the Socratic problem on the basis of the logoi sokratikoi:

I suggest that this comparative study of the Socratic literature can be a useful substitute for that old but ultimately fruitless attempt to define the relationship between the Platonic and the historical Socrates. The historical Socrates certainly existed, but to a very large extent the fifth-century figure escapes our grasp. What we have instead is the literary Socrates of the fourth century, in a diversity of portraits. (Kahn I990, p. 287)

Plato and Xenophon were not the only authors of Socratic dialogues. Many of Socrates' followers contributed to this genre. The conventions of the genre seem to have allowed authors considerable freedom to reshape Socrates, idealize him, and put their own views in Socrates' mouth. Therefore the cautious and reasonable view is that certainty about the historical Socrates is lost to us - and, in a way, not very important. The most important fact about Socrates was his influence: the extraordinary fertility of his ideas and the moral example he set for his followers. (Morrison 2000a, p. 780)

Some might accuse comparative exegesis of being a sort of literary pastime that abandons any aspiration to a historical understanding of Socrates' texts and character. We can respond to this objection by pointing out that comparative exegesis is rather, on the historical level, the most appropriate approach given the nature of the logoi sokratikoi. If the various Socratics composed the logoi sokratikoi not only from an apologetic perspective but also in order to promote their own respective representations of Socrates in opposition to representations put forth by other Socratics, only comparative exegesis, freed from the Socratic problem, is really up to the task of grasping and interpreting the differences among the logoi sokratikoi that are, in a way, the very reason for their existence and diversity. If the historical Socrates' philosophy is out of our reach, the logoi sokratikoi only offer us a "diffraction" of Socrates' character and ideas, or, in other words, the different and often conflicting interpretations that his disciples have given of his life and ideas. 
Only comparative exegesis seems in a position to identify the Socratic themes that were the subject of such diffraction and, above all, to give a comprehensive account of each divergent interpretation of each theme found in the Socratic literature. ${ }^{51}$

(3) As for Socrates' posterity within ancient philosophy, we should pursue the already numerous studies that attempt to show how, on the one hand, the majority of later philosophers (Stoics, Academics, Neo-Platonists) appropriated the figure of Socrates, and for what reasons, on the other hand, certain others (notably the Peripatetics and the Epicureans) were opposed to him.

Gigon's skepticism has often incited profound hostility, no doubt because such a position was feared to lead inevitably to the disappearance of Socrates. ${ }^{52}$ This fear is unfounded since the type of exegesis that Gigon recommended in fact allows for a better evaluation of the actual historical breadth of the Socrates' character and his numerous portraits. Paradoxically, it is the Socratic problem that leads to a double denial of history: by chasing an elusive Socrates hopelessly out of reach, it finds only a pseudo-historical Socrates all while ostracizing accounts reputedly irreconcilable with this simulacrum of the historical Socrates; by doing so, the Socratic problem obstructs a fair historical understanding of the efficiency of different representations of Socrates in the history of philosophy. Historians of Socrates and Socratism thus have their work cut out, and this is why bothering with the useless and cumbersome Socratic problem is no longer of interest to them.

\section{WORKS CITED}

Beversluis, J. "Vlastos's Quest for the Historical Socrates." Ancient Philosophy I3 (I993): 293-3I2.

Brickhouse, T. C., and Smith, N. D. Socrates on Trial. Oxford, I 989.

Brickhouse, T. C., and Smith, N. D. The Philosophy of Socrates. Boulder, 2000.

Brickhouse, T. C., and Smith, N. D. 2003. "Apology of Socratic Studies." Polis 20 (2003): I08-I 27.

Burnet, J. Plato's Phaedo. Oxford, i9 I I.

Burnet, J. Greek Philosophy: Thales to Plato. London, I9 4.

Deman, T. Le Témoignage d'Aristote sur Socrate. Paris, I942.

Döring, K. "Der Sokrates der Platonischen Apologie und die Frage nach dem historischen Sokrates." Würzburger Jahrbücher für die Altertumswissenschaft I4 (I987): 75-94.

5 I Vander Waerdt (1993, pp. 4-5) also makes the case for this exegetic project.

52 See Montuori r981a, p. 45; I988, pp. I, 33; 1992, p. 24I; Graham 1992, p. I 43, n. II. 
Döring, K. "Die Philosophie des Sokrates." Gymnasium 99 (I992): I-I6.

Dorion, L. -A., and M. Bandini. Xénophon: Mémorables, vol. I: Introduction générale et Livre I [Introduction, translation, and notes by L.-A. Dorion. History of the Greek text by M. Bandini]. Paris, 2000.

Dorion, L. -A. "A l'origine de la question socratique et de la critique du témoignage de Xénophon: l'étude de Schleiermacher sur Socrate (I8I5)." Dionysius I9 (200I): 5 I-74.

Dorion, L. -A. "Akrasia et enkrateia dans les Mémorables de Xénophon." Dialogue 42 (2003): 645-672.

Dorion, L. -A. 2005. "The Daimonion and the Megalêgoria of Socrates in Xenophon's Apology." In Socrates' Divine Sign: Religion, Practice, and Value in Socratic Philosophy, eds. P. Destrée and N. D. Smith. Kelowna, B.C., Canada, 2005, pp. I $27-143$.

Dorion, L. -A. 2006. "Xenophon's Socrates," In A Companion to Socrates, eds. S. Ahbel-Rappe and R. Kamtekar. Oxford, 2006, pp. 93-Io9.

Dover, K. J. Aristophanes' Clouds. Oxford, I968.

Dupréel, E. La légende socratique et les sources de Platon. Brussels, I 922.

Gigon, O. Socrates. Sein Bild in Dichtung und Geschichte. Bern, I947.

Gomperz, H. "Die sokratische Frage als geschichtliches Problem." Historische Zeitschrift I29 (1924): 377-423, repr. in Patzer 1987: I 84-224.

Graham, D. W. "Socrates and Plato." Phronesis 37 (I992): I4I-I65.

Guthrie, W. K. C. Socrates. Cambridge, I97I.

Guthrie, W. K. C. A History of Greek Philosophy, vol. IV. Cambridge, I 975.

Joël, K. Der echte und der xenophontische Sokrates, 3 vol. Berlin, I893-I90I.

Joël, K. "Der logos Sokratikos". AGP (I895-I 896): 466-483; 9: 50-66.

Kahn, C. H. "Did Plato Write Socratic Dialogues?" CQ 3I (I98I): 305-320.

Kahn, C. H. "Plato as a Socratic." Hommage à Henri Joly. Recherches sur la philosophie et le langage I 2 (I990): 287-30I.

Kahn, C. H. "Vlastos's Socrates." Phronesis 37 (I992): 233-258.

Kahn, C. H. Plato and the Socratic Dialogue. Cambridge, I996.

Long, A. A. I988. "Socrates in Hellenistic Philosophy." CQ 38 (I988): I 50-I7I; repr. in Stoic Studies. Cambridge, I996.

Luccioni, J. Xénophon et le socratisme. Paris, I953.

Magalhães-Vilhena, V. de. Le problème de Socrate: le Socrate historique et le Socrate de Platon. Paris, 1952.

Maier, H. Sokrates, sein Werk und seine geschichtliche Stellung. Tübingen, I9I3.

Momigliano, A. The Development of Greek Biography. Cambridge, I97 I.

Montuori, M. Socrates: Physiology of a Myth. Amsterdam, I98 Ia.

Montuori, M. De Socrate iuste damnato. The Rise of the Socratic Problem in the Eighteenth Century. Amsterdam, 198Ib.

Montuori, M. Socrates: An Approach. Amsterdam, 1988.

Montuori, M. The Socratic Problem. The History, the Solutions. Amsterdam, I992.

Morrison, D. "Xenophon." In Greek Thought. A Guide to Classical Knowledge, eds. J. Brunschwig and G.E.R. Lloyd. Cambridge, MA, 2000 .

Morrison, D. "On the Alleged Historical Reliability of Plato's Apology." AGP 82 $(2000 b): 235-265$.

Patzer, A. I987. "Einleitung," In Der historische Sokrates, ed. A. Patzer. Darmstadt, I987, pp. I-40. 
Robin, L. "Les Mémorables de Xénophon et notre connaissance de la philosophie de Socrate." Année philosophique 2 I (1910): I-47, repr. in La Pensée hellénique. Paris, I942.

Ross, W. D. "The Problem of Socrates." Proceedings of the Classical Association 30 (I933): 7-24.

Santas, G. X. Socrates: Philosophy in Plato's Early Dialogues. London, I 979.

Schleiermacher, F. "Ueber den Werth des Sokrates als Philosophen," Abhandlung der philosophischen Klasse der königlich preussichen Akademie aus den Tahren I8I4-I8I5. I8I8: 5 I-68; repr. in Patzer I987: 4I-58. English trans.: "The Worth of Socrates as Philosopher," PLATON: The Apology of Socrates, the Crito and part of the Phaedo, ed. W. Smith. London, I879.

Tarrant, D. "The Pseudo-platonic Socrates." CQ 32 (I938): I67-I73.

Taylor, A. E. Varia Socratica. Oxford, I9II.

Taylor, A. E. Socrates. London, I932.

Vander Waerdt, P. A. "Socratic Justice and Self-sufficiency. The Story of the Delphic Oracle in Xenophon's Apology of Socrates." OSAP I I (I993): I-48.

Vander Waerdt, P.A., ed. The Socratic Movement. Ithaca, I 994.

Vlastos, G. "The Paradox of Socrates," In The Philosophy of Socrates. A Collection of Critical Essays. ed. G. Vlastos. Garden City, NY, I97 I, pp. I-2 I.

Vlastos, G. "Socrates." PBA 74 (I988): 89-I I I.

Vlastos, G. Socrates: Ironist and Moral Philosopher. Ithaca, I99I. 